\title{
THE TWO KRISHNAS: THE STORY OF THE EXILED SOULS
}

\author{
ASWATHY M ARAVINDAN ${ }^{1} \&$ BALAKRISHNAN. $K^{2}$ \\ ${ }^{l}$ M.Phil English, Department of English and Languages, Amrita School of Arts and Sciences, Kochi \\ ${ }^{2}$ Professor and Research Supervisor, Department of English and Languages, Amrita School of Arts and Sciences, Kochi
}

ABSTRACT
Ghalib Shiraz. Dhalla, A Los Angeles based novelist was born in Mombasa, Kenya. He is famous for his novel
Ode ToLata published in 2002, which was later adapted to film in 2008 under the title The Ode. The novel The Two
Krishnas was published in 2011, which was released as The Exilesin India. The novel is drawn from the romantic sufi
poetry and archetypal Hindu mythology. The novel portrays the life in Los Angeles, especially that of the immigrant
Indian community. The book discusses about how love and life and other emotions move us in to action. It's about how
we form our own identities and questions our duties to our families and our self. It's the story of PoojaKapoor, a
successful caterer, who lost herself when her husband Rahul, a successful banker, has given his heart to a young Muslim
boy Atif. Through these characters, he gives us the definition of right, wrong, sin, redemption, and morality. He also talks
about the acceptance of same-sex love among Indian Community.
KEYWORDS: Same-Sex Love, Vatsayana, Kama Sutra \& Gandharvavivaha

Received: Jun 25, 2017; Accepted: Jul 18, 2017; Published: Jul 31, 2017; Paper Id.: IJELAUG201719

\section{INTRODUCTION}

The Two Krishnas is a novel written by Los Angeles based writer- director- producer, Ghalib Shiraz Dhalla. He was born in Kenya, a syndicated columnist, his work has appeared in various national publications and celebrated at MIT. His critically acclaimed debut novel Ode to Latawas hailed as an achievement by the Los Angeles Times. In 2008, Dhalla turned Ode to Lata into the major motion picture The Ode. He is a passionate activist and the co-founder of the South Asian program at the Asian Pacific Aids Intervention Team, and is one of the founding members of Satrang, a support group for LGBT.

Lisa See, the Author of Shanghai Girls commented that, The Two Krishnas is a beautiful, sometimes joyful yet heartbreaking exploration of love in all its manifestation. Chitra Banerjee Divakarunicommented that, The novel is filled with unexpected turns and beauty, and the author is examining with perceptive compassion the complex and heart- wrenching ties that bind families and the secret desires that pull them apart. And, in the words of BapsiSidhwa, Dhalla immerses us in gripping narratives as he delves into the nooks and crannies of human desire and explores both its splendor and the havoc it can wreck.

It's the tragic story of Rahul, Pooja, Atif and Ajay. The story starts with Rahul, a middle aged family man falling in love with a boy, who is almost of the age of his own son. They indulge in violent sexual relationships. And, this relationship resulted in the breakdown of Rahul's family. He started ignoring Pooja who badly need her husband's company. They were pulled apart and this affected Pooja in a serious way. The news of her husband's gay relationship with an Indian boy almost shattered her. Seeing his mother's sorrow, Ajay decides 
to talk to his father and secretly follows him, while he was going to Atif's apartment after his office hours. Ajay was shocked to know the truth of his father being a gay and in that fury, he kills Atif and runs away and met with an accident and dies. Pooja is the one, who is the real victim of this tragedy. She loses both her husband and her son and she was forced to question her beliefs and marriage when her husband falls in love with a boy. She is compelled to confront the painful truths about the past, the duality of god and her Husband and the secrets that threaten to destroy everything in their life.

The lives of all the major characters are revolving around Rahul. He is the center and he is the only one who survives after the tragedy. Atifis killed by Ajay and Ajay died in an accident and in that shock Pooja commits suicide. Rahul is alive and was forced to withstand all this tragedy he finds himself guilty of the death of all these characters. Thus, this novel spans three generation and evokes an unforgettable love triangle to explore how, with a new world comes new freedom and with them, the choices that could change everything we knew about the ones we love.

Even though this story was set in Los Angeles, we could see all the characters behaving in an Indian way. Both Rahul and Pooja was born and brought up in Kenya and it is quite absurd to see them behaving like a typical traditional Indians. As a reader, we would feel that the author's actual intention was to write a novel which was actually set in an Indian city. But, the subject of homosexuality may be one reason for him to change the settings of the novel, since the concept of same sex love is a taboo topic in India.

It is widely believed that the concept of same sex love is not visibly there in the culture of India. Even Foucault claimed that the concept of sexual identity was first invented in nineteenth century Europe, and no such things existed before. But, some historians have challenged that and they found some visible examples of the existence of queer sexuality in the archives of Indian culture. The studies of major theorists like Ruth Vanita and Kidwai is tracing back these discourses to the ancient India, which is quite complex.

One of the major forms of same sex love in India is through friendship. In Hindu mythology, the relationship between Krishna and Arjuna is quite controversial. They are often referred to as Two Krishans. Other ways of representing same sex love in India is through rebirth, divine intervention. Vatsyayana, in his book Kamasutra categories different types of sexual behavior. He divides men into two types, those who dress and behave like woman and those who dress and behave like man. Foucault's claim was proven wrong that categorization person according to their sexual behavior was first done by late nineteenth century western psychologists and sexologist. Similar categorization was done in ancient Indian texts. Vatsyana used the term "third nature" to denote person based on his sexual desire.

\section{In the Novel "The Two Krishnas"Dhalla Begins the Novel with Two Quotes:}

O Dhananjaya, I bless you, my dear friend. There is no one equal to you in the three worlds, as you know my secret. O Arjuna, you will curse me if you talk to anyone about the secret which you wanted to know and have experienced. (Krishna to Arjuna, Padmapurana)

The one and only wife should with internalized belief and total absorption, hold her husband as God. (Kamasutra)

These two quotes denote the whole essence of the story. In the first quote, it is between Krishna and Arjuna thus the title The Two Krishna may denote the relationship between Rahul and Atif and in the second quote, it is about the 
qualities of a dutiful wife, may be referring to Pooja and how she considered Rahul as her Lord Krishna. Rahul is a character who sways between the two sides of his mind. He cannot leave his wife and son and at the same time he cannot stop himself from loving Atif.

We can force ourselves to tolerate certain people, to acclimate to a job we detest. But, we are truly helpless against the heart and its obdurate desires.(Dhalla, 4)

In the case of Pooja, she is a devoted wife, whose life revolves around her husband and son. She is a devotee of Lord Krishna and sees Rahul as her God.

Many years later, just after she had turned eighteen, Rahul becomes her dark God.... In the adoration Rahul inspired in his friends and the amorousness in the girls, in the charismatic way he flirted and compelled others to do his bidding without asking, and the way flocks of people followed him on sports field and in social gatherings, Pooja recognized her Krishna. (Dhalla, 12-13)

Even if she was born and brought up in Kenya, she always behaved like a traditional Indian woman, who always finds solace in their family. She always wears sari, teardrop-shaped bindis and buttery gold jhumkas. She is a typical housewife, who finds happiness in being with her family, she is one who saves money, and one who cries when she is lonely.

Yes, I know money grows on trees so father and son can be as wasteful as they like. Somebody around here has to act responsibly (24).

Atif is an Indian boy, who was forced to leave his homeland when his family found his actual sexuality. He was more a woman than a man, he loves to dance to Bollywood songs. Atif lived in Bombay in Byculla, which was once a prosperous and elegant suburb with grand British and Parsi houses. He was a boy, who loves to dance to Bollywood songs and he always played the role of the Damsel. He was not interested in the male roles

Atif wasn't interested in the sauve choreography of the male leads, the comparatively reined-in emotions, the mysterious frowms.... He rejoiced in the expansive seductive moves of the actress- the undulating shoulders, hip thrusts, trance- like spins...(90-91).

Once his mother caught him enacting a bollywood song of Geeta Dutt, and at that time, he first sensed something with what had naturally come to him. He was first exploited by his uncle and his aunt Zainab was his greatest support. She gave him strength by saying, "Brace up, dear boy. If this is the path you'll be walking, you're going to need all the strength you can muster(102). When he was eighteen, he left Bombay for America. All these relationship started with Hiten Khanna, the son of wealthy parents. He took Atif to their first gay club in West Hollywood. Soon Hiten dropped out from his college and his parents blamed Atiffor making him a gay. Atif's parents also abandoned him for that. He gradually lost contact with his family and stopped contacting them because, they never accepted his unique sexuality.

So, you could turn into a sinner, rub your nose in the dirt? Better we are dead- dead- than to hear this. Better you had died than to become like this.... You are dead for us...Don't ever call here again. Forget you have a mother and father. Unless you can change, unless you can repent in front of Allah, do not bother to come back.(47-48)

"Self- acceptance was the prerequisite to tolerance from others"(42). This was the realization he gained when he moved on to Los Angeles. He tried to seek the answers of his questions from the books of god. He started that with Koran 
where he finds the words being quite contradictory. He searched Shiva Purana. Old and New Testament and found that the Old Testament vehemently condemned homosexuality. He found that same-sex love was accepted only in Sufism and Hinduism through their mythical tales and poems, even though they are highly intolerant about that.

Legendary mystics like Jelaluddin Rumi and Faridud-Din Attar had written evocatively about the love between two men- the ecstacy in their melding, the scorn and outrage it incited amongst the people, and the superhuman lengths to which such lovers went to keep their love alive. The tales of Shiva and Agni, of Shiva and Vishnu, Krishna and Arjuna, again validated Atif.(43)

$\mathrm{He}$ is offended by the fact that the believers are ignoring these facts and homogenizing them in the figure of a Loving God. Atif feels that it was people's inability to digest such relationship that compelled them to unnecessary interpretation, and in doing so they completely missed one point that, loving one person regardless of their sex was a way of loving God.

Ancient Hindu scriptures list different kind of marriages. Gandharvavivaha is one among them and in Kamasutra it is stated as the best form of marriage because it is based on mutual attraction. It is a marriage that takes place without any rituals and ceremonies and thus homosexuals in India since they are considered unusual, tend to follow the comprehensible form of Gandharvavivaha. Same sex desire or activity was discussed in Indian Literature only during the past few years. Most of the Indian nationalists considered homosexuality as an unspeakable crime. Many institutions like Police force, educational and religious organizations, responded to homosexuality with violence. It is the same case with the families in India. They even resist heterosexual love marriages and the degree of resistance ranges from family to family.

For Pooja, Rahul was her husband and her lord and even after so many years of marriage her desire for him was not dissipated. She feels that her place was with her husband and her child and it was not easy for her to get up and leave for a holiday. When Pooja came to know about his homosexual affair, she was completely shattered. When Sonali told her about her seeing Rahul kissing an Indian boy, she was not ready to believe that.

A boy? What does she mean by 'a boy'? She must mean a woman. A boy?... No, this couldn't be. This is some kind of sick joke. Sonali has finally gone completely, stark, raving crazy....(204)

When she met Atif at the book shop she completely lost her mind and she started blaming herself to drive Rahul into this kind of relationship she felt that it is her platonic love towards her husband and the sanitary life without sex caused Rahul to fall in relationship with another man. Her only solace was to cry in front of her beloved pair Radha and Krishna but she suddenly found that the pair, whom she looked upon as divine couple, was themselves unfaithful, philanderers married to other people.

As an Indian reader, we would be naturally sympathizing with Pooja. She was a woman who considered her husband as her God and at last her life was destroyed. Rahul who followed his sexual desire may not be considered as the sole person responsible for her tragic life. It was her faith, her over dependency on her husband that destroyed her. When Rahul was away from her she started to lean on the shoulders of her son Ajay. She was a woman who always wanted to be under the protection of a strong man, be thatRahul, Ajay, or Charlie. After Rahul leaving her and the sudden death of her son Ajay in an accident, she completely lost her mind and there was no way in front of her other than suicide. She was a woman who never thought of living independently. Even if she is having the ability to live alone, she behaves like a coward. It may be because, since she was portrayed as a traditional Indian wife, for whom the concept of Pativrata remains 
a superior one, it was not possible to think of a life without the name of her husband.

\section{CONCLUSIONS}

Each and every character in the novel are portrayed with a strong Indian base. It may be Rahul, Pooja, Atif or Sonali. Rahul was a man who was trapped in the cobwebs of society. It was hard for him to choose between his family and his love. He is the one upon whom the tragedy falls. He lost his family and his love and is left alone. Thus, the novel The Two Krishnas can be identified as an ideal Indian story, since the homosexual affair was not successful in the life of the protagonists. We could see the novelist pointing out towards the duality of man and god. In the novel, same sex love was curbed in the same way as the concept of homosexuality was put aside from our traditional concepts and myths.

\section{REFERENCES}

1. Clark, Anna, and Elizabeth W.Williams, editors.History of Sexuality.Vol.3.Routledge, 2015.

2. Dasgupta K, Rohit. "Queer Sexuality: A Cultural Narrative of India's Historical Archives".Rupkatha Journal on Interdisciplinary studies in Humanities. ISSN 0975-2935, vol. 3.No.4, 2011, pp.651-670.

3. Halperin M, David. "Forgetting Foucault: Acts, Identities, and the History of Sexuality". History of Sexuality, edited by Anna Clark and Elizebeth W. Williams. Vol.1. Routledge, 2015, pp 238-266.

4. SirazDhalla, Ghalib. The Two Krishnas.Magnus Books,2011.

5. Vanita, Ruth. "Same-sex weddings, Hindu Traditions, and Modern India". 06 Mar 2009, www.springer.com, 2009.

6. ---. "Same-sex Love in India". Translating Desire, edited by Brinda Bose, Katha,2002, pp 168-181.

7. Vijayan, P.K. "Outline for an Exploration of HindutvaMasculanities". Translating Desire, edited by Brinda Bose, Katha, 2002, $p$ p 82-105. 
